Riddle et al. (r945) and Urist (1959). The mean level of diffusible Ca in the plasma during egg-shell calcification is about $8.4 \mathrm{mg} / 100 \mathrm{ml}$, but in some individuals it may fall to $7.6 \mathrm{mg} / 100 \mathrm{ml}$, and there is no reason to believe that this latter figure represents a minimum (Taylor \& Hertelendy, 196r).

It may be claimed with some justification that the laying capacity of a hen is directly related to her ability to absorb and metabolize $\mathrm{Ca}$, and these functions are largely under hormonal control. Nutrition and endocrinology are in fact so closely interrelated in the $\mathrm{Ca}$ metabolism of the laying hen that they cannot be considered separately with any degree of understanding.

\title{
REFERENCES
}

Bloom, M. A., Domm, L. V., Nalbandov, A. V. \& Bloom, W. (1958). Amer. F. Anat. ro2, 4 I I.

Bloom, W., Bloom, M. A. \& McLean, F. C. (1941). Anat. Rec. 81, 443.

Bradfield, J. R. G. (195 I). F. exp. Biol. 28, 125.

Burmester, B. R., Scott, H. M. \& Card, L. E. (1939). World's Poult. Congr. vil, Cleveland, Ohio, p. 99.

Common, R. H., Rutledge, W. A. \& Hale, R. W. (1948). F. agric, Sci. 38, 64.

Copp, D. H. (1964). Recent Progr. Hormone Res. 20, 59.

Copp, D. H., Cameron, E. C., Cheney, B. A., Davidson, A. G. F. \& Henze, K. G. (1962). Endocrinology, 70,638 .

Fussell, M. H. (1960). Studies on calcium and phosphorus metabolism in the hen. Ph.D. Thesis, University of Cambridge.

Hertelendy, F. ( 1962 ). Biochemical studies on the tissues of the domestic fowl in relation to reproduction. Ph.D. 'Thesis, University of Reading.

Macowan, M. M. (x93 I-2). Quart. F. exp. Physiol. 21, 383 .

Riddle, O., Rauch, V. M. \& Smith, G. C. (1945). Endocrinology, 36, 4 I.

Stringer, D. A. (1962). The chemistry and physiology of bone, with special reference to medullary bone in the fowl. Ph.D. Thesis, University of Reading.

Taylor, T. G. \& Hertelendy, F. (I961). Poult. Sci. 40, I 5.

Taylor, T. G. \& Moore, J. H. (I954). Brit. F. Nutr. 8, i I 2.

Taylor, T. G., Morris, T. R. \& Hertelendy, F. (1962). Vet. Rec. 74, 123.

Tyler, C. (1954). F. Sci. Fd Agric. 5, 335.

Urist, M. R. (I959). Recent Progr. Hormone Res. 15, 455.

Urist, M. R., Deutsch, N. M., Pomerantz, G. \& McLean, F. C. (1960). Amer. F. Physiol. 199, 85 I.

Warren, D. C. \& Scott, H. M. (1935). Poult. Sci. 14, 195.

\section{The importance of hypocalcaemia in the development of hypomagnesaemic tetany}

By R. G. Hemingway and N. S. Ritchie, Department of Animal Husbandry and Preventive Veterinary Medicine, Glasgow University Veterinary School, Bearsden, Glasgow

It is generally considered that the normal concentration of magnesium in the blood plasma of cattle is within the range $2 \cdot 0-2 \cdot 5 \mathrm{mg} / \mathrm{I} 00 \mathrm{ml}$. Allcroft (1947a) has defined hypomagnesaemia as being associated with concentrations below $1 \cdot 7 \mathrm{mg}$ $\mathrm{Mg} / \mathrm{I} 00 \mathrm{ml}$. Rook \& Balch (1958) regarded $\mathrm{r} \cdot 8 \mathrm{mg} \mathrm{Mg} / \mathrm{I} 00 \mathrm{ml}$ as the lower limit of the normal range, and Butler ( 1963 ) designated concentrations of $\mathrm{Mg}$ below $\mathrm{I} \cdot 8$ $\mathrm{mg} / 100 \mathrm{ml}$ as hypomagnesaemic. Many other authorities would accept this value of $\mathrm{I} \cdot 7^{-1} \cdot 8 \mathrm{mg} / \mathrm{I} 00 \mathrm{ml}$ as being the lower limit of the normal range. Hypomagnesaemia is not however synonymous with clinical tetany. Although Butler (1963) recorded an $8.7 \%$ incidence of hypomagnesaemia $(<\mathrm{I} .8 \mathrm{mg} \mathrm{Mg} / 100 \mathrm{ml}$ ) in a survey covering 
some 5000 cows in Scotland during the spring grazing period, the actual incidence of clinical tetany was only $\mathrm{I} \cdot \mathrm{I} \%$. Clinical tetany was recorded in $25 \%$ of the 108 herds studied, but hypomagnesaemia (<r.8 $\mathrm{mg} \mathrm{Mg} / \mathrm{roO} \mathrm{ml}$ ) was detected in clinically normal cows in $4 \mathrm{r} \%$ of the herds.

There are many reports in the literature to indicate that individual cows in a particular herd may experience severe hypomagnesaemia without showing signs of clinical tetany. Allcroft \& Green (1938) recorded that in a group of fifty-two cows twelve had plasma $\mathrm{Mg}$ concentrations between 0.5 and $1.0 \mathrm{mg} / 100 \mathrm{ml}$ and a further twenty-nine animals had values within the range $\mathrm{I} \cdot 0-\mathrm{r} \cdot 5 \mathrm{mg} / \mathrm{r} 00 \mathrm{ml}$. There was no clinical tetany. Bartlett, Brown, Foot, Rowland, Allcroft \& Parr (1954) reported experiments involving forty-two cows. Eight had plasma Mg concentrations between 0.6 and $1.0 \mathrm{mg} / \mathrm{r} 00 \mathrm{ml}$ and a further eighteen cows had values at or below $0.6 \mathrm{mg} / 100$ $\mathrm{ml}$. Of these eighteen, only five showed signs of grass tetany and two others died suddenly. Hughes \& Cornelius (1960) found that, in a herd of sixteen cows, seven had plasma $\mathrm{Mg}$ concentrations between 1.0 and $1.5 \mathrm{mg} / \mathrm{I} 00 \mathrm{ml}$ and a further nine (of which only two died of clinical tetany) had concentrations between 0.5 and $\mathrm{I} \cdot 0$ $\mathrm{mg} / 100 \mathrm{ml}$. Kemp, Deijs, Hewkes \& van Es ( 1960 ) have presented data concerning the plasma $\mathrm{Mg}$ concentrations of 822 cows in Holland. There were twenty-three cases of clinical tetany of which seventeen were associated with plasma Mg concentrations below $0.5 \mathrm{mg} / 100 \mathrm{ml}$ and six with values between 0.5 and $1.0 \mathrm{mg} / 100 \mathrm{ml}$. There were, however, fifteen healthy cows with values below $0.5 \mathrm{mg} / 100 \mathrm{ml}$ and as many as 126 with concentrations between 0.5 and $1.0 \mathrm{mg} / 100 \mathrm{ml}$ which showed no signs of tetany. Walsh \& Conway (I960) found that only two of seven cows with plasma $\mathrm{Mg}$ concentrations below $\mathrm{I} \cdot 0 \mathrm{mg} / \mathrm{I} 00 \mathrm{ml}$ became clinically affected. Birch \& Wolton (196I) reported only two clinical cases of tetany in a herd of eighteen cows. They recorded, however, four blood samples with concentrations of under $0.5 \mathrm{mg}$ $\mathrm{Mg} / \mathrm{r} 00 \mathrm{ml}$ and a further ten with values between 0.5 and $1.0 \mathrm{mg} / 100 \mathrm{ml}$. Storry (196r) in an experiment involving sixteen cows on heavily fertilized herbage found that three animals had plasma $\mathrm{Mg}$ concentrations between 0.6 and $\mathrm{I} \cdot 0 \mathrm{mg} / \mathrm{I} 00 \mathrm{ml}$ but that none exhibited clinical tetany. McConaghy, McAllister, Todd, Rankin \& Kerr ( 1963 ) found that of eighteen cows, five had plasma Mg concentrations below $\mathrm{I} \cdot 0 \mathrm{mg} /$ IOo $\mathrm{ml}$ but there were no signs of tetany.

Other workers who have recorded severe hypomagnesaemia in cattle (below $I^{\circ} \circ$ $\mathrm{mg} / \mathrm{r} 00 \mathrm{ml}$ and frequently below $0.5 \mathrm{mg} / 100 \mathrm{ml}$ ) without clinical signs of tetany include Muth \& Haag (1945), Breirem, Ender, Halse \& Slagsvold (1949), Bartlett, Brown, Foot, Head, Line, Rook, Rowland \& Zundel (1957), Ender, Dishington \& Helgebostad (1957), Simesen (1957), Kemp (1958), Line, Head, Rook, Foot \& Rowland (1958) and Rook \& Balch (1958).

It is thus evident that severe hypomagnesaemia in cattle is not necessarily the only factor involved in the precipitation of clinical tetany. Allcroft $(1947 a, b)$ has reported the remarkably high incidence of $76 \%$ of animals having hypomagnesaemia $(<\mathrm{I} \cdot 7$ $\mathrm{mg} \mathrm{Mg} /$ / $00 \mathrm{ml}$ ) which had a concomitant hypocalcaemia $(<8.4 \mathrm{mg} \mathrm{Ca} /$ /oo ml).

This finding prompted a survey of the literature covering cases of clinical tetany in cattle for which both $\mathrm{Ca}$ and $\mathrm{Mg}$ concentrations in the plasma have been 
quoted. Table I summarizes these findings. Many other reports concerning clinical hypomagnesaemia cannot be quoted in this context as unfortunately $\mathrm{Ca}$ analyses were not apparently undertaken.

Table I. Plasma calcium and magnesium concentrations in 244 cases of clinical tetany in cattle

Reference

Sjollema (1930)

Allcroft \& Green (r934)

Metzger (1936)

Nicholson \& Shearer (1938)

Nolan \& Hull (194I)

Breirem et al. (1949)

McBarron (1952)

Inglis, Weipers \&

Pearce (1959)

Ender et al. (I957)

Simesen (1957)

Weighton (1957)

Mershon \& Custer (1958)

Hughes \& Cornelius (I960)

Storry (I96I)

Rook (1963)

Mean for 126 cases

\section{Dryerre (1932)}

Hopkirk, Marshall \&

Blake ( 1933 )

Weighton (1942)

Ender et al. (1948)

Bartlett et al. (1954)

Bartlett et al. (1 957)

Smyth, Conway \&

Walsh (1958)

Butler (1963)

Mean for 118 cases

Overall mean for 244 cases

\begin{tabular}{|c|c|c|c|c|}
\hline \multirow{2}{*}{$\begin{array}{l}\text { No. of } \\
\text { cases }\end{array}$} & \multicolumn{2}{|c|}{ Plasma Ca $(\mathrm{mg} / 100 \mathrm{ml})$} & \multicolumn{2}{|c|}{ Plasma $\mathrm{Mg}(\mathrm{mg} / \mathrm{i} 00 \mathrm{ml})$} \\
\hline & Mean & Range & Mean & Range \\
\hline \multicolumn{5}{|c|}{ Individual values given } \\
\hline 55 & $6 \cdot 65$ & $3.90-9 \cdot 50$ & 0.45 & $0.16-1 \cdot 16$ \\
\hline 18 & $7 \cdot 30$ & $4.60-10.90$ & 0.64 & $0.35^{-1} \cdot 15$ \\
\hline I & $7 \cdot 50$ & - & 0.15 & - \\
\hline 2 & $6 \cdot 50$ & $5 \cdot 70-7 \cdot 30$ & 0.75 & $0.52-0.99$ \\
\hline 12 & $6 \cdot 63$ & $4 \cdot 90-8 \cdot 35$ & 0.90 & $0 \cdot 10-2 \cdot 46$ \\
\hline 3 & $6 \cdot 10$ & $5 \cdot 60-6 \cdot 90$ & 0.46 & $0.32-0.55$ \\
\hline 2 & $4 \cdot 10$ & $3 \cdot 70-4 \cdot 40$ & $1 \cdot 45$ & $I \cdot 30-I \cdot 60$ \\
\hline 1 & $11 \cdot 8$ & - & 0.58 & - \\
\hline 2 & $6 \cdot 30$ & $5 \cdot 10-7 \cdot 50$ & 0.30 & $0.20-0.40$ \\
\hline 3 & $5 \cdot 23$ & $4 \cdot 90-5 \cdot 40$ & 0.70 & $0.66-0.75$ \\
\hline 1 & $6 \cdot 30$ & - & 0.60 & - \\
\hline 20 & $6 \cdot 3 \circ$ & $4 \cdot 20-9 \cdot 80$ & 0.70 & $0.10-1 \cdot 70$ \\
\hline 2 & $6 \cdot 50$ & $6 \cdot 00-7 \cdot 00$ & 0.63 & $0.60-0.67$ \\
\hline 3 & $6 \cdot 3^{6}$ & $6 \cdot 24-6 \cdot 44$ & 0.73 & $0.57-0.8 \mathrm{I}$ \\
\hline 1 & $6 \cdot 80$ & - & 0.19 & - \\
\hline \multicolumn{3}{|c|}{6.49} & 0.58 & \\
\hline \multicolumn{5}{|c|}{ Individual values not given } \\
\hline 42 & $9 \cdot 30$ & $5 \cdot 60-11 \cdot 00$ & $0 \cdot 39$ & $0 \cdot 10-I \cdot I 6$ \\
\hline 35 & 7.00 & $4 \cdot 50-9 \cdot 60$ & $0.8 \mathrm{I}$ & $0 \cdot 30-1 \cdot 50$ \\
\hline 13 & $7 \cdot 40$ & 一 & $1 \cdot 00$ & - \\
\hline 8 & $6 \cdot 65$ & - & 0.71 & - \\
\hline 6 & - & $6 \cdot 80-8.00$ & - & $<0.60$ \\
\hline $\mathbf{I}$ & $>8.00$ & - & $<0.60$ & - \\
\hline 2 & $>8.00$ & 一 & 0.70 & - \\
\hline \multirow[t]{3}{*}{ I I } & $5 \cdot 97$ & $2 \cdot 9 \mathrm{I}-8 \cdot \mathrm{II}$ & $1 \cdot 27$ & $0.58-1.75$ \\
\hline & $7 \cdot 68$ & & 0.71 & \\
\hline & 7.02 & & 0.64 & \\
\hline
\end{tabular}

\section{Clinical tetany in cattle}

Amongst the earliest relevant papers concerning cattle were those of Sjollema (1930), Dryerre (1932), Hopkirk et al. (1933) and Allcroft \& Green (1934). Sjollema (I930) reported fifty-five clinical cases. The mean and range of plasma $\mathrm{Ca}$ and $\mathrm{Mg}$ concentrations were $6.65(3.90-9.50)$ and $0.45(0 \cdot \mathrm{I} 6-\mathrm{I} \cdot \mathrm{I} 6)$ $\mathrm{mg} / \mathrm{ro0} \mathrm{ml}$ respectively. Eighteen of the fifty-five animals had plasma $\mathrm{Ca}$ values below $6.0 \mathrm{mg} / 100 \mathrm{ml}$. Twenty-two had values between 6.0 and 8.0 , and fifteen above $8.0 \mathrm{mg} / 100 \mathrm{ml}$. Hopkirk et al. (1933) did not present values for individual cows, but for a total of thirty-five clinical cases the mean plasma $\mathrm{Ca}$ concentration was $7 \cdot 0$ $\mathrm{mg} / \mathrm{I} 00 \mathrm{ml}$ and the range was $4 \cdot 5-9 \cdot 6$. The mean plasma $\mathrm{Mg}$ concentration was $0 \cdot 8 \mathrm{I}$ $\mathrm{mg} / \mathrm{r} 00 \mathrm{ml}$. In contrast, nine healthy cows on a farm where clinical tetany was 
occurring had a mean plasma Ca concentration of $9.2 \mathrm{mg} / 100 \mathrm{ml}$ and there were no individual values below 8.0. Allcroft \& Green (I934) presented information concerning eighteen individual clinical cases. The mean plasma $\mathrm{Ca}$ and $\mathrm{Mg}$ concentrations were 7.30 and $0.64 \mathrm{mg} / 100 \mathrm{ml}$ respectively. Only five of the eighteen cows had plasma Ca concentrations above $8.0 \mathrm{mg} / 100 \mathrm{ml}$. Eight had values between 6.0 and 8.0 and a further five had values below $6.0 \mathrm{mg} / 100 \mathrm{ml}$. In marked contrast, however, Dryerre (r932) claimed that hypocalcaemia was not involved in clinical tetany and that only two of forty-two samples showed plasma $\mathrm{Ca}$ concentrations below $8 \cdot 0$ $\mathrm{mg} / \mathrm{I} 00 \mathrm{ml}$.

Many other workers have subsequently confirmed a generally occurring condition of hypocalcaemia accompanying hypomagnesaemia in clinical tetany. Nolan \& Hull (I94I) found for twelve clinical cases that the mean plasma $\mathrm{Ca}$ and $\mathrm{Mg}$ concentrations were $6.6_{3}$ and $0.90 \mathrm{mg} / 100 \mathrm{ml}$ respectively. There were five individuals with plasma Ca values below $6.0 \mathrm{mg} / \mathrm{I} 00 \mathrm{ml}$, five between 6.0 and 8.0 and only two above 8.0 . Weighton (1942) reported mean $\mathrm{Ca}$ and $\mathrm{Mg}$ concentrations of $7 \cdot 4$ and $\mathrm{I} \cdot 0 \mathrm{mg} / \mathrm{I} 00 \mathrm{ml}$ for thirteen confirmed clinical cases of tetany. Ender, Halse \& Slagsvold (1948) quoted mean values of $6.65 \mathrm{mg} \mathrm{Ca} / 100 \mathrm{ml}$ and $0.7 \mathrm{I} \mathrm{mg} \mathrm{Mg} / \mathrm{r} 00 \mathrm{ml}$ for eight clinically affected cows. Mershon \& Custer (I958) reported that only four of twenty cows with clinical grass tetany had plasma Ca levels above $8.0 \mathrm{mg} / 100 \mathrm{ml}$ but that eleven had values between 4.0 and 6.0 and the remaining five had values between 6.0 and 8.0 . Butler ( 1963 ) recorded the mean and range of plasma $\mathrm{Ca}$ and $\mathrm{Mg}$ concentrations for eleven cows before treatment to correct clinical signs. The range of $\mathrm{Ca}$ concentrations was $2.9 \mathrm{I}-8.8 \mathrm{I}$ (mean $5.97 \mathrm{mg} / \mathrm{I} 00 \mathrm{ml}$ ) and the comparable values for $\mathrm{Mg}$ were $0.5^{8-1} \cdot 75$ (mean $1.27 \mathrm{mg} / 100 \mathrm{ml}$ ).

Several workers have detailed the plasma $\mathrm{Ca}$ and $\mathrm{Mg}$ values of isolated clinical cases together with values for the remaining unaffected cattle in the herd. They have drawn attention to the marked importance of reduced plasma Ca concentrations in clinical tetany and considered this to be the prime feature in distinguishing this condition from hypomagnesaemia without tetany. In a series of experiments Bartlett et al. (1954) recorded a total of eighteen cows with plasma Mg concentrations at or below $0.6 \mathrm{mg} / 100 \mathrm{ml}$ of which five showed clinical tetany and two others died suddenly. The data for plasma $\mathrm{Ca}$ concentrations were not reported in detail but they regarded it as noteworthy that in the clinical cases of grass tetany values in the range $6 \cdot 8-8.0 \mathrm{mg} / 100 \mathrm{ml}$ were recorded within $2-3$ days before signs or death occurred. On the other hand, where low serum $\mathrm{Mg}$ values were recorded without any marked change in the $\mathrm{Ca}$ concentrations (i.e. maintenance in the range $8 \cdot 0-10 \cdot 9$ $\mathrm{mg} / \mathrm{ro0} \mathrm{ml}$ ) no clinical signs were recorded. Simesen (1957) reported three clinical cases for which the ranges of plasma $\mathrm{Ca}$ and $\mathrm{Mg}$ values were $4 \cdot 9-5 \cdot 4$ and $0.66-0.75$ $\mathrm{mg} / \mathrm{r} 00 \mathrm{ml}$ respectively. In contrast, three other unaffected animals in the herd had $\mathrm{Mg}$ values below $\mathrm{I} \cdot 0 \mathrm{mg} / 100 \mathrm{ml}$, but the $\mathrm{Ca}$ concentrations were normal at $9.5-9.8$ $\mathrm{mg} / \mathrm{ro0} \mathrm{ml}$. Hughes \& Cornelius (1960) found that the two cows that had clinical tetany in a herd of sixteen had plasma Ca values of 7.0 and 6.0 and $\mathrm{Mg}$ levels of 0.60 and $0.67 \mathrm{mg} / 100 \mathrm{ml}$ respectively. A further five animals which showed no signs of tetany had equally low $\mathrm{Mg}$ values of $0.52-0.75 \mathrm{mg} / \mathrm{I} 00 \mathrm{ml}$ but these were associated 
with a range of from 9.0 to $10.0 \mathrm{mg} \mathrm{Ca} / \mathrm{r} 00 \mathrm{ml}$. Storry (I96r) reported no cases of clinical tetany in an experiment in which individual $\mathrm{Mg}$ values fell as low as $0.6-0.7$ $\mathrm{mg} / \mathrm{roO} \mathrm{ml}$ and plasma $\mathrm{Ca}$ concentrations remained normal. In contrast, however, there were three cases of clinical tetany in cattle on an adjacent field at the same time. For these animals the plasma $\mathrm{Ca}$ concentrations ranged from $6 \cdot 24$ to 6.44 and were combined with $\mathrm{Mg}$ levels in the range $0.57-0.81 \mathrm{mg} / \mathrm{I00} \mathrm{ml}$.

Table 2. Percentage distribution of plasma calcium and magnesium concentrations of 126 cows with clinical tetany

\begin{tabular}{|c|c|c|c|c|}
\hline \multirow{2}{*}{$\begin{array}{l}\text { Plasma Ca } \\
(\mathrm{mg} / 100 \mathrm{ml})\end{array}$} & \multicolumn{3}{|c|}{ Plasma $\mathrm{Mg}(\mathrm{mg} / 100 \mathrm{ml})$} & \multirow{2}{*}{$\begin{array}{c}\% \text { of samples } \\
\text { within each } \mathrm{Ca} \\
\text { concentration } \\
\text { range }\end{array}$} \\
\hline & $\underbrace{0.0-0.5}$ & $\underbrace{0.5^{-1.0}}$ & $\underbrace{\mathrm{I} \cdot \mathrm{O}-\mathrm{I} \cdot 75}$ & \\
\hline $\begin{array}{c}<4 \cdot 0-6 \cdot 0 \\
6 \cdot 0-8 \cdot 0 \\
>8 \cdot 0\end{array}$ & $\begin{array}{r}18 \cdot 8 \\
24 \cdot 5 \\
8 \cdot 7\end{array}$ & $\begin{array}{r}\text { I } 2 \cdot 6 \\
\text { I } 8 \cdot 8 \\
8 \cdot 7\end{array}$ & $\begin{array}{l}4 \cdot 7 \\
\mathrm{I} \cdot 6 \\
\mathrm{I} \cdot 6\end{array}$ & $\begin{array}{l}36 \cdot 1 \\
44 \cdot 9 \\
19 \cdot 0\end{array}$ \\
\hline $\begin{array}{c}\% \text { of samples } \\
\text { within each } \mathrm{Mg} \\
\text { concentration } \\
\text { range }\end{array}$ & $52 \cdot 0$ & $40 \cdot 1$ & $7 \cdot 9$ & $100 \cdot 0$ \\
\hline
\end{tabular}

Table 2 summarizes the plasma $\mathrm{Ca}$ and $\mathrm{Mg}$ values for the $\mathrm{2} 6 \mathrm{clinical}$ cases detailed in the first part of Table I for which individual values are quoted. A total of $74.7 \%$ of the clinical cases were associated with combined plasma concentrations of under $8.0 \mathrm{mg} \mathrm{Ca} / 100 \mathrm{ml}$ and under $\mathrm{I} .0 \mathrm{mg} \mathrm{Mg} / \mathrm{I} 00 \mathrm{ml}$. Only $19 \%$ of clinical cases were associated with $\mathrm{Ca}$ values above $8.0 \mathrm{mg} / 100 \mathrm{ml}$. The mean values for both $\mathrm{Ca}$ and Mg given by Hopkirk et al. (1933), Weighton (1942), Ender et al. (1948) and Butler (1963) confirm the importance of a combined hypocalcaemia and hypomagnesaemia where clinical tetany is concerned.

\section{Hypomagnesaemia in sheep}

Hemingway \& Ritchie (1963) found that the mean plasma $\mathrm{Mg}$ concentration for 389 ewes in twelve flocks about I month after lambing was $\mathrm{I} \cdot 68 \mathrm{mg} / 100 \mathrm{ml}$. Clinical tetany was not a problem in these flocks (two cases in 389 ewes) although some $15 \%$ of individuals had concentrations below $1.0 \mathrm{mg} / 100 \mathrm{ml}$. In two separate flocks of twenty-four ewes the mean plasma $\mathrm{Mg}$ values were as low as 0.99 and $\mathrm{I} \cdot \mathrm{I} 3 \mathrm{mg} / \mathrm{I} 00$ $\mathrm{ml}$, and over $50 \%$ of the ewes had values below $\mathrm{I} \cdot 0 \mathrm{mg} / \mathrm{I} 00 \mathrm{ml}$. It was frequently recorded that ewes with lambs could have plasma $\mathrm{Mg}$ concentrations of the order of $0.25^{-0.50} \mathrm{mg} / 100 \mathrm{ml}$ for long periods with no sign of clinical tetany in the flock. One group of twenty-four ewes had as many as $25 \%$ of the individuals in this category.

In a further experiment Hemingway, Ritchie, Brown \& Peart (1965) found a mean plasma $\mathrm{Mg}$ concentration as low as $0.75 \mathrm{mg} / \mathrm{r}$ oo $\mathrm{ml}$ for forty-four lactating ewes of which only four had clinical tetany (which was associated with a combined hypocalcaemia). However, twenty more of the ewes had plasma $\mathrm{Mg}$ concentrations below $0.5 \mathrm{mg} / \mathrm{r} 00 \mathrm{ml}$ on at least one sampling occasion and showed no signs of tetany. 
Allcroft ( 1960 ) has indicated that individual ewes may have plasma $\mathrm{Mg}$ values as low as $0.7 \mathrm{mg} / 100 \mathrm{ml}$ without experiencing clinical tetany, and Herd \& Peebles (1962) reported values as low as $0.5 \mathrm{mg} / 100 \mathrm{ml}$ in apparently normal ewes. Inglis et al. (1959), Michael (196r), Owen \& Sinclair (196r) and L'Estrange \& Axford $(1964 a, b)$ have also shown that plasma $\mathrm{Mg}$ concentrations of lactating ewes may fall below $1.0 \mathrm{mg} / 100 \mathrm{ml}$ without the ewes necessarily showing clinical signs.

In a survey of 298 outbreaks of sudden death in sheep, Watt (1960) concluded that some $12 \%$ were due to hypomagnesaemia, $5 \%$ to a combined hypocalcaemia and hypomagnesaemia and $8 \%$ to hypocalcaemia alone. A survey of the literature has indicated that a combined hypocalcaemia and hypomagnesaemia is, however, almost invariably involved in the clinical condition in lactating ewes. Individual plasma $\mathrm{Ca}$ and $\mathrm{Mg}$ concentrations in sixteen cases of clinical tetany in lactating ewes together with a further six cases in non-lactating sheep are presented in Table 3.

Table 3. Plasma calcium and magnesium concentrations in twenty-two cases of clinical tetany in sheep

\begin{tabular}{|c|c|c|c|c|c|}
\hline \multirow[b]{2}{*}{ Reference } & \multirow{2}{*}{$\begin{array}{l}\text { No. of } \\
\text { cases }\end{array}$} & \multicolumn{2}{|c|}{ Plasma Ca $(\mathrm{mg} / 100 \mathrm{ml})$} & \multicolumn{2}{|c|}{ Plasma Mg $(\mathrm{mg} / \mathrm{r} 00 \mathrm{ml})$} \\
\hline & & Mean & Range & Mean & Range \\
\hline O'Moore (I955) & 2 & 6.00 & - & $I \cdot 20$ & - \\
\hline Penny \& Amold (1955) & 3 & 3.66 & $3 \cdot 20-4 \cdot 20$ & 0.73 & $0.70-0.80$ \\
\hline Inglis et al. (x959) & I & $3 \cdot 40$ & - & 1.07 & - \\
\hline McAleese \& Forbes (1959) & $5^{*}$ & $6 \cdot 42$ & $6 \cdot 40-6 \cdot 50$ & 0.51 & $0.40-0.60$ \\
\hline Michael (I $96 \mathrm{I}$ ) & I & 2.80 & - & 1.60 & - \\
\hline Herd \& Peebles ( 1962 ) & I & $7 \cdot 00$ & - & 0.70 & - \\
\hline Ritchie et al. (1962) & I* & $9 \cdot 80$ & - & 0.73 & - \\
\hline Hemingway \& Richie ( 1963 ) & I & $4 \cdot 00$ & - & 0.46 & - \\
\hline Hemingway et al. ( 1965$)$ & 4 & $5 \cdot 13$ & $3 \cdot 79-5 \cdot 89$ & 0.40 & $0.25-0.50$ \\
\hline L'Estrange \& Axford (1964a) & 2 & $4 \cdot 85$ & $3 \cdot 70-6 \cdot 00$ & $0.3^{6}$ & $0.20-0.5^{2}$ \\
\hline L'Estrange \& Axford (r964b) & $\mathbf{I}$ & $4 \cdot 16$ & - & 0.58 & - \\
\hline Mean & & $5 \cdot 3 \mathbf{I}$ & & 0.66 & \\
\hline
\end{tabular}

*Non-lactating sheep fed on low-Mg diets.

With the exception of a plasma Ca concentration of $9.8 \mathrm{mg} / 100 \mathrm{ml}$ recorded by Ritchie, Hemingway, Inglis \& Peacock (1962), for a non-lactating ewe on a Mgdeficient diet, all the remaining cases of clinical tetany were associated with values below $6.5 \mathrm{mg} / 100 \mathrm{ml}$ and about half were connected with $\mathrm{Ca}$ concentrations below $5.0 \mathrm{mg} / 100 \mathrm{ml}$. Plasma Mg concentrations below $0.8 \mathrm{mg} / 100 \mathrm{ml}$ were recorded for the majority of the sheep. O'Moore (1955) contrasted mean values of $6 \cdot 0$ and $\mathrm{I} \cdot 2$ $\mathrm{mg} / \mathrm{I} 00 \mathrm{ml}$ of $\mathrm{Ca}$ and $\mathrm{Mg}$ respectively for two clinical cases of tetany with mean values of 9.5 and $1.4 \mathrm{mg} / 100 \mathrm{ml}$ for four healthy ewes in the same flock. Similarly, Herd \& Peebles (1962) have contrasted a single clinical case of tetany in a lactating ewe $(7.0 \mathrm{mg} \mathrm{Ca}, 0.70 \mathrm{mg} \mathrm{Mg} / 100 \mathrm{ml})$ with mean values of $9.25 \mathrm{mg} \mathrm{Ca}$ and $0.77 \mathrm{mg}$ $\mathrm{Mg} / \mathrm{r}$ oo $\mathrm{ml}$ for four healthy ewes in the same flock. Inglis et al. (1959) recorded that for the ten blood samples taken from flocks in which clinical tetany was occurring, plasma $\mathrm{Mg}$ concentrations ranged from 0.25 to $\mathrm{I} \cdot 07 \mathrm{mg} / \mathrm{I} 00 \mathrm{ml}$. One ewe had a 
plasma Ca level below $6.0 \mathrm{mg} / 100 \mathrm{ml}$, four had values between 6.0 and 8.0 and five above $8.0 \mathrm{mg} / \mathrm{ro0} \mathrm{ml}$. Only limited value can however be placed on the examination of blood samples from healthy animals in a flock in which clinical tetany has occurred, in that healthy animals may not necessarily reflect the same trends as those individuals which are clinically affected. Hemingway et al. (1965) recorded four clinical cases of combined hypocalcaemia and hypomagnesaemia in a flock of forty-four ewes (Table 3 ). Four other ewes in this flock had plasma Ca levels below $7.0 \mathrm{mg} / 100 \mathrm{ml}$, associated with $\mathrm{Mg}$ concentrations of under $0.65 \mathrm{mg} / 100 \mathrm{ml}$, but clinical tetany did not ensue. On the other hand, Hemingway \& Ritchie ( 1963$)$ reported only two low $\mathrm{Ca}$ values in some $38 \mathrm{~g}$ ewes, $15 \%$ of which had plasma $\mathrm{Mg}$ values of under 1.0 $\mathrm{mg} / \mathrm{ro0} \mathrm{ml}$. These were associated with the only two clinical cases of tetany recorded. A combined hypocalcaemia $\left(<7^{\circ} 0 \mathrm{mg} \mathrm{Ca} / 100 \mathrm{ml}\right)$ and hypomagnesaemia $(<0.7$ $\mathrm{mg} \mathrm{Mg} / \mathrm{I} 00 \mathrm{ml}$ ) must therefore be considered to confer a very high degree of risk of clinical tetany such as would not occur as a result of this degree of hypomagnesaemia alone.

\section{Changes in plasma Ca and Mg during the development of clinical tetany}

Table 4 presents data concerning changes in plasma $\mathrm{Ca}$ and $\mathrm{Mg}$ concentrations in lactating ewes during the few days before the onset of clinical signs. A striking feature of these cases was the existence of low plasma $\mathrm{Mg}$ levels for several days before the development of clinical tetany. The mean fall over the critical 4 days was only from 0.63 to $0.42 \mathrm{mg} / 100 \mathrm{ml}$. In marked contrast all eight ewes showed pronounced falls in plasma Ca concentrations, generally during the $24 \mathrm{~h}$ immediately before the appearance of clinical tetany. A mean concentration of about $8.5 \mathrm{mg} / 100$ $\mathrm{ml}$ was maintained from the period $4-2$ days before tetany. This value fell to a mean of $7.45 \mathrm{mg} / \mathrm{r} 00 \mathrm{ml}$ on the day before tetany, followed by a rapid and severe fall to a mean concentration of $4.8 \mathrm{I} \mathrm{mg/100} \mathrm{ml}$ during the last $24 \mathrm{~h}$.

Table 4. Changes in plasma calcium and magnesium concentrations during the development of clinical tetany in eight lactating ewes

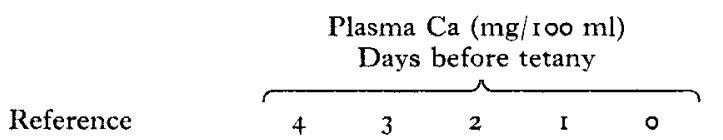

Hemingway \& Richie (1963) 6.80

Hemingway et al. (1965)

$\begin{array}{ccccc} & 8.63 & 8.23 & & 5.89 \\ & 7.98 & 7.02 & & 3.79 \\ 8.55 & 7.82 & & 8.79 & 5.48 \\ & & 9.35 & & 5.48\end{array}$

L'Estrange \& Axford (1964a)

L'Estrange \& Axford $(1964 b)$

Mean

$\begin{array}{ccccc}8.20 & 9.40 & 10.20 & 8.20 & 3.70 \\ & & & & \\ 10.50 & 11.50 & 9.80 & 6.80 & 6.00 \\ & & 5.50 & 6.00 & 4.16 \\ 8.51 & 8.69 & 8.35 & 7.45 & 4.16\end{array}$

Plasma Mg (mg/100 $\mathrm{ml})$ Days before tetany

$\begin{array}{ccccc}4 & 3 & 2 & \text { I } & 0 \\ 0.45 & & & & 0.46 \\ & & & & \\ & 0.80 & 0.50 & & 0.50 \\ 0.65 & 0.40 & 0.30 & & 0.25 \\ & 0.50 & & 0.50 & 0.45 \\ & & 0.50 & & 0.40\end{array}$

$\begin{array}{lllll}0.60 & 0.65 & 0.60 & 0.50 & 0.52 \\ 0.82 & 0.82 & 0.45 & 0.30 & 0.20 \\ & & 0.58 & 0.56 & 0.58 \\ 0.63 & 0.63 & 0.49 & 0.46 & 0.42\end{array}$


Comparable data for cattle are difficult to obtain, but Ender et al. (1948) have reported a similar picture to that for sheep for eight cases of clinical tetany in cattle. Two to five days before the onset of tetany mean plasma $\mathrm{Ca}$ and $\mathrm{Mg}$ concentrations were 9.9 and $0.72 \mathrm{mg} / 100 \mathrm{ml}$ respectively. The changes in mean values at the onset of tetany were to $6.65 \mathrm{mg} \mathrm{Ca} / 100 \mathrm{ml}$ and to $0.7 \mathrm{I} \mathrm{mg} \mathrm{Mg} / \mathrm{I} 00 \mathrm{ml}$. Rook (1963) found that the plasma $\mathrm{Mg}$ concentration of a cow kept on a low-Mg diet fell to $0.5 \mathrm{mg} / \mathrm{roo}$ $\mathrm{ml}$ after 4 days. At this stage the cow refused to consume concentrates (which contained supplementary $\mathrm{Ca}$ ). Within $36 \mathrm{~h}$ the plasma $\mathrm{Ca}$ level dropped from above Io to $6.8 \mathrm{mg} / \mathrm{roo} \mathrm{ml}$, when the cow collapsed. The plasma $\mathrm{Mg}$ level at this time was $0.19 \mathrm{mg} / 100 \mathrm{ml}$.

Parr \& Allcroft (1953) have reported a number of clinical cases of hypomagnesaemic tetany in milk-fed calves. For all the animals there were low serum concentrations of both $\mathrm{Ca}$ and $\mathrm{Mg}$. In some calves serum Mg levels fell to as low as $0.4 \mathrm{mg} / \mathrm{r} 00 \mathrm{ml}$, but clinical signs did not appear until serum Ca levels also fell. The mean values for eight calves that died or were killed in tetany were $6.2 \mathrm{mg} \mathrm{Ca} / 100 \mathrm{ml}$ and 0.6 $\mathrm{mg} \mathrm{Mg} / \mathrm{I} 00 \mathrm{ml}$. They further indicated that blood samples submitted from clinical cases on a variety of farms showed a similar picture. Parr (1957) later showed that a plasma Mg concentration of $0.6 \mathrm{mg} / \mathrm{I} 00 \mathrm{ml}$ associated with tetany in a 12 week-old calf, typical of several others, had persisted for at least 3 weeks before the first signs. The plasma Ca concentration had been $9.6 \mathrm{mg} / 100 \mathrm{ml}$ at 9 weeks, 9.1 at 10 weeks, 7.4 at $1 \mathrm{I}$ weeks and finally fell to $6.0 \mathrm{mg} / \mathrm{I} 00 \mathrm{ml}$ at $\mathrm{I} 2$ weeks when tetany occurred. In contrast, another calf, typical of others that did not succumb to tetany, had a plasma $\mathrm{Mg}$ concentration of $0.5 \mathrm{mg} / 100 \mathrm{ml}$, but the Ca level never fell below io $\mathrm{mg} / 100 \mathrm{ml}$. Smith $(1957$, 1958, I961) has also indicated that in milk-fed calves a prolonged reduction in plasma $\mathrm{Mg}$ concentration is eventually followed by a reduction in plasma $\mathrm{Ca}$ values. Much earlier, Huffman \& Robinson (1926) associated hypocalcaemia with hypomagnesaemia in calves but later Duncan, Huffman \& Robinson (I935) and Huffman \& Duncan (1936) considered that this form of tetany was associated with a simple hypomagnesaemia alone. Todd \& Rankin (1959) also recorded hypomagnesaemia $(<0.6 \mathrm{mg} / \mathrm{I} 00 \mathrm{ml})$ without hypocalcaemia $(>9.0$ $\mathrm{mg} / \mathrm{I} 00 \mathrm{ml}$ ) in clinical tetany of milk-fed calves.

Blaxter \& Sharman (1955) showed for a large number of calves that as plasma $\mathrm{Mg}$ concentrations fell progressively from above $2.0 \mathrm{mg} / 100 \mathrm{ml}$ to about $\mathrm{I} \cdot 0 \mathrm{mg} / \mathrm{I} 00$ $\mathrm{ml}$ there was no change in plasma $\mathrm{Ca}$ levels. When plasma $\mathrm{Mg}$ values fell below about $0.8 \mathrm{mg} / 100 \mathrm{ml}$ a proportion $(10 \%)$ of calves had reduced plasma Ca concentrations $(<8.0 \mathrm{mg} / 100 \mathrm{ml})$ and some individual values were less than $7.0 \mathrm{mg} / 100 \mathrm{ml}$. Parr (I957) found that $8 \mathrm{~g} \mathrm{Mg} /$ day given as magnesium carbonate to a calf not only restored the plasma $\mathrm{Mg}$ level but also increased the plasma $\mathrm{Ca}$ concentration from $7^{\cdot}$ I to $9.8 \mathrm{mg} / \mathrm{I} 00 \mathrm{ml}$ within 6 days. Parr, however, was unable to increase the plasma $\mathrm{Ca}$ concentration in a $\mathrm{Mg}$-depleted calf by giving supplementary dietary $\mathrm{Ca}$. The diet was adequately supplemented with vitamin D. Smith (I96r) also recorded that $\mathrm{Mg}$ given either orally or by injection increased both plasma $\mathrm{Ca}$ and plasma $\mathrm{Mg}$ concentrations in Mg-depleted calves. Smith (1957, 1958) had earlier shown that the severe hypocalcaemia (but not the hypomagnesaemia) induced in milk-fed calves 
was alleviated by high dietary levels of vitamin $D$. There can be no question of a dietary insufficiency of $\mathrm{Ca}$ in milk-fed calves, and Blaxter \& Sharman (1955) showed that there was no demineralization of bone $\mathrm{Ca}$.

McAleese \& Forbes (I959), working with lambs fed indoors on a low-Mg diet, recorded that as serum $\mathrm{Mg}$ concentrations were reduced to the order of $0.9^{-1 \cdot 2}$ $\mathrm{mg} /$ Ioo $\mathrm{ml}$ serum Ca levels decreased quite rapidly to as low as $6.5 \mathrm{mg} / \mathrm{I} 00 \mathrm{ml}$. Additional $\mathrm{Ca}$ and vitamin $\mathrm{D}$ had no influence on these low $\mathrm{Ca}$ and $\mathrm{Mg}$ concentrations. L'Estrange \& Axford (1964b) in three separate experiments involving ten lactating ewes fed on a low-Mg diet, found that when plasma Mg concentrations fell to below I. $\circ \mathrm{mg} / \mathrm{I} 00 \mathrm{ml}$, plasma $\mathrm{Ca}$ concentrations were reduced to $4^{-6} \mathrm{mg} / \mathrm{I} 00 \mathrm{ml}$ although the diet contained adequate $\mathrm{Ca}$. Supplementary dietary Mg increased both plasma $\mathrm{Ca}$ and plasma $\mathrm{Mg}$ concentrations to normal within a few days. They considered that a low concentration of plasma $\mathrm{Mg}$ was more important in inducing hypocalcaemia than either loss of appetite or the accompanying low plasma citric acid concentration. In contrast, Ritchie et al. (1962) observed no hypocalcaemia when non-lactating ewes were fed on a low-Mg diet which induced severe hypomagnesaemia and one case of clinical tetany.

\section{Conclusion}

The majority of cases of clinical tetany in cattle, sheep and milk-fed calves exhibit a combined hypocalcaemia and hypomagnesaemia. In many circumstances all these ruminants seem to be able to experience severe hypomagnesaemia for long periods without signs of clinical tetany. There is evidence to indicate that the actual onset of clinical signs of tetany is in some way associated with a rapid fall in plasma $\mathrm{Ca}$ concentration superimposed on an existing state of hypomagnesaemia.

Supplementary $\mathrm{Mg}$ has been shown to increase both plasma $\mathrm{Mg}$ and plasma $\mathrm{Ca}$ concentrations in circumstances in which supplementary $\mathrm{Ca}$ is unable to influence either plasma $\mathrm{Ca}$ or plasma $\mathrm{Mg}$ levels. This may be taken as an indication that severe hypomagnesaemia in some way interferes with plasma Ca metabolism, as has been suggested by Blaxter \& Sharman (r955), Neuman \& Neuman (1958) and Smith (I96I).

Vitamin D, by influencing plasma Ca may possibly have a role in affecting the incidence of clinical tetany although having no influence on plasma $\mathrm{Mg}$ concentrations.

\section{REFERENCES}

Allcroft, R. (1960) In Conference on Hypomagnesaemia, November 23rd \& 24th, I960, p. 120. ILondon: The British Veterinary Association.

Allcroft, W. M. (1947a) Vet. F. 103, 2.

Allcroft, W. M. (1947b) Vet. F. 103, 30.

Allcroft, W. M. \& Green H. H. (1934). Biochem. F. 28, 22,20.

Allcroft, W. M. \& Green H. H. (r 938). Y. comp. Path. 51, i 76.

Bartlett, S., Brown, B. B., Foot, A. S., Head. M. J., Line, C., Rook, J. A. F., Rowland, S. J. \& Zundel, G. (1957). F. agric. Sci. 49, 29 r.

Bartlett, S., Brown, B. B., Foot, A. S., Rowland, S. J., Allcroft, R. \& Parr, W. H. (r954). Brit. vet. $\mathcal{F}$. II0, 3 .

Birch, J. A. \& Wolton, K. M. (196r). Vet. Rec. 73, I 699.

Blaxter, K. L. \& Sharman, G. A. M. (1955). Vet. Rec. 67, го8.

Breirem, K., Ender, F., Halse, K. \& Slagsvold, I. (I949). Acta agric. suec. 3, 89. 
Butler, E. J. (1963). F. agric. Sci. 6o, 329.

Dryerre, H. (1932). Vet. Rec. I2, I 163 .

Duncan, C. W., Huffman, C. F. \& Robinson, C. S. (1935). $\%$. biol. Chem. ro8, 35.

Ender, F., Dishington, I. W. \& Helgebostad, A. (1957). Nord. VetMed. 9, 881.

Ender, F., Halse, K. \& Slagsvold, P. (1948). Norsk. VetTidsskr. 6o, I.

Hemingway, R. G. \& Ritchie, N. S. (1963). F. Sci. Fd Agric. 14, 162.

Hemingway, R. G., Ritchie, N. S., Brown, N. A. \& Peart, J. N. (1965). Y. agric. Sci. (In the Press.)

Herd, R. P. \& Peebles, R. M. (rg62) Aust. vet. F. 38, 455 .

Hopkirk, C. S. M., Marshall, D. \& Blake, T. A. (I933). Vet. Rec. 13, 355.

Huffman, C. F. \& Duncan, C. W. (1936). F. Dairy Sci. 19, $44^{\circ}$.

Huffman, C. F. \& Robinson, C. S. (1926). J. biol. Chem. 69, ror.

Hughes, J. P. \& Cornelius, C. E. (1960). Cornell Vet. 50, 26.

Inglis, J. S. S., Weipers, M. \& Pearce, P. J. (1959). Vet. Rec. 7r, 755.

Kemp, A. (1958). Netherlands F. agric. Sci. 6, 28 r.

Kemp, A., Deijs, W. B., Hewkes, O. J. \& van Es, A. J. H. (1960). In Conference on Hypomagnesaemia, November 23rd \& 24th, I960, p. 23. London: The British Veterinary Association.

L'Estrange, J. L. \& Axford, R. F. E. (1964a). F. agric. Sci. 62, 341.

L'Estrange, J. L. \& Axford, R. F. E. (1964b). J. agric. Sci. 62, 353.

Line, C., Head, M. J., Rook, J. A. F., Foot, A. S. \& Rowland, S. J. (1958). F. agric. Sci. 5r, 353.

McAleese, D. M. \& Forbes, R. M. (I959). Nature, Lond., r84, 2025.

McBarron, E. J. (1952). Aust. vet. $7.28,36$.

McConaghy, S., McAllister, J. A. V., Todd, J. R., Rankin, J. E. F. \& Kerr, J. (1963). J. agric. Sci. 6o, 313.

Mershon, M. M. \& Custer, F. D. (1958). F. Amer. vet. Med. Ass. 132, 396.

Metzger, H. J. (1936). Cornell Vet. 26, 353.

Michael, D. T. ( I 961). Vet. Rec. 73, 7 I 8.

Muth, O. H. \& Haag, J. R. (1945). N. Amer. Vet. 26, 216.

Neuman, W. F. \& Neuman, M. W. (1958). The Chemical Dynamics of Bone Mineral, p. 33. Chicago: University Press.

Nicholson, J. A. \& Shearer, G. D. (1938). Vet. F. 94, 388.

Nolan, A. F. \& Hull, F. E. (194I). Amer. F. vet. Res. 2, 4I.

O'Moore, L. B. (1955). Irish vet. 7. 9, 95.

Owen, J. B. \& Sinclair, K. B. (1961). Vet. Rec. 73, 1423.

Parr, W. H. (1957). Vet. Rec. 69, 7 I.

Parr, W. H. \& Allcroft, R. (1953). Proc. Nutr. Soc. 12, vii.

Penny, R. H. C. \& Arnold, J. H. S. (1955). Vet. Rec. 67, 772.

Ritchie, N. S., Hemingway, R. G., Inglis, J. S. S. \& Peacock, R. M. (1962). F. agric. Sci. 58, 399.

Rook, J. A. F. (1963). F. comp. Path. 73, 93.

Rook, J. A. F. \& Balch, C. C. (1958). F. agric. Sci. 51, 199.

Simesen, M. G. (1957). Nord. VetMed. 9, 305.

Sjollema, B. (1930). Vet. Rec. Io, 425.

Smith, R. H. (1957). Biochem. F. 67, 472.

Smith, R. H. (1958). Biochem. F. 70, 201.

Smith, R. H. (I96I). Nature, Lond., I9I, I8I.

Smyth, P. J., Conway, A. \& Walsh, M. J. (I958). Vet. Rec. 7o, 846.

Storry, J. E. (1961). Res. vet. Sci. 2, 272.

Todd, J. R. \& Rankin, J. E. F. (1959). Vet. Rec. 7r, 256.

Walsh, M. J. \& Conway, A. (I960). Proc. int. Grassl. Congr. vili, Reading, p. 548.

Watt, J. A. A. (1960). Vet. Rec. 72, 998.

Weighton, C. (1942). Vet. Rec. 54, 49.

Weighton, C. (1957). Brit. vet. F. 113, 263.

\section{Renal mechanisms of potassium depletion}

\section{By Anne T. Lambie, Department of Therapeutics, University of Edinburgh}

In an age in which we are coming to rely more and more upon the results of laboratory investigations as an aid to diagnosis it is perhaps salutary to remember that such investigations are frequently of little value in the diagnosis of potassium depletion. The vast majority of the body $\mathrm{K}$ is within the cells, and as a result the 